\title{
Sikap Masyarakat Lampung terhadap Bahasa Nenek Moyang
}

\author{
Windo Dicky Irawan ${ }^{1}$ \\ Program Studi Pendidikan Bahasa dan Sastra Indonesia \\ STKIP Muhammadiyah Kotabumi Lampung
}

\begin{abstract}
Abstrak
This paper focuses on the attitude of the native language speakers of Lampung. This study describes the attitude of the language of the people of Lampung to the language of his ancestors. The results of the study found that all respondents were not embarrassed to use their local language in their own areas, but $15 \%$ of respondents were embarrassed to use local language outside Lampung. Based on the integrative function, there is a tendency of people in Lampung to have a positive attitude towards their language. Meanwhile, with reference to the instrumental function, there is a tendency that they have a negative attitude towards language and a positive attitude towards Bahasa Indonesia.
\end{abstract}

\section{A. PENDAHULUAN}

Sikap merupakan reaksi dari seseorang yang dilihat, didengar, dan diamati terhadap suatu obyek. Sikap adalah cara yang efisien dan tepat untuk menjelaskan pola yang konsisten tentang perilaku. Sikap tidak dapat dilihat langsung tetapi hanya dapat di tafsirkan terlebih dahulu dari perilaku yang tertutup. Lambert \& Lambert, (1973:72) mengatakan bahwa sikap seseorang merujuk kepada bentuk pemikiran, perasaan dan tindak balasnya yang tersusun dan konsisten ke atas individu, kumpulan, isu-isu sosial maupun peristiwa-peristiwa di sekitar. Dengan demikian, dapat dinyatakan bahwa pada kajian bahasa memandang bahasa sebagai perilaku. Sementara itu, pandangan mentalist, yang memiliki asumsi bahwa konsep seperti "pikiran" dan "sikap" memiliki beberapa realitas objektif meskipun sikap tidak dapat diamati secara langsung.

Dalam tulisan ini, sikap bahasa merujuk kepada sikap satu kelompok masyarakat atau sesuatu komunitas terhadap sesuatu bahasa, seperti bahasa itu menarik, sedap didengar, mudah dipelajari dan sebagainya (Ghazali Yusri, Nik Mohd Rahimi \& Parilah M. Shah, 2010:17). Berkembang dari itu, tulisan ini coba memaparkan sikap bahasa masyarakat Lampung terhadap bahasa nenek moyangnya sendiri. 
Menurut Baker (1992: 32), penelitian tentang sikap selama ini telah menempatkan dua komponen sikap bahasa, yaitu motivasi instrumental dan integratif. Motivasi instrumental mencakupi motif kebermanfaatan, memusatkan perhatian pada keuntungan yang dapat digapai, keinginan untuk mencapai pengakuan sosial atau keuntungan ekonomi melalui pengetahuan bahasa asing, orientasi diri, peningkatan diri, atau kebutuhan untuk berprestasi. Motivasi instrumental dapat berupa alasan profesionalitas, status, prestasi, keberhasilan pribadi, peningkatan diri, aktualisasi diri, atau dasar keamanan dan bertahan hidup. Sementara itu, motivasi integratif mencakupi aspek sosial dan interpersonal dalam orientasi, hubungan konseptual dengan kebutuhan untuk berafiliasi, keinginan menjadi anggota representatif dari komunitas bahasa lain, identifikasi dengan kelompok bahasa dan aktivitas kebudayaan mereka, dan bagian dari keinginan untuk mengetahui lebih tentang, untuk berinteraksi dengan, dan mungkin untuk membaurkan dirinya sendiri dalam, kebudayaan lain.

Ada beberapa faktor dalam penelitian sikap bahasa, yaitu usia, status sosial, jender, jenjang pendidikan, kompetensi, penggunaan bahasa, latar kebudayaan, dan kontak bahasa. Pengaruh berbagai faktor tersebut memang tidak begitu nampak langsung, tetapi penting kiranya untuk mempertimbangkan situasi dari perspektif itu. Disamping itu, ada beberapa faktor perlu untuk dipertimbangkan secara bersamaan dan juga beberapa faktor dapat saling berpengaruh satu sama lain.

Penelitian sikap bahasa tertuju pada tingkat yang berbeda-beda. Pertama, sikap bahasa terhadap bahasa atau ragam bahasa itu sendiri, misalnya mencakupi sikap negatif atau positif. Kedua, sikap terhadap bahasa/ragam bahasa dan penuturnya, misalnya sikap terhadap dialek daerah; sikap terhadap aksen: ciri variabel dalam bahasa orang itu sendiri; sikap terhadap sosiolek: usia, kelas sosial, profesi, dan etnisitas; sikap terhadap "bahasa asli" di daerah tertentu; sikap terhadap bahasa imigran. Ketiga, sikap yang dimanifestasikan dalam ragam bahasa, misalnya penggunaan bahasa lisan, penggunaan bahasa tulis (keberaksaraan, kesastraan), penggunaan bahasa publik dan pribadi dan lebih spesifik ranah penggunaan bahasa; penggunaan bahasa di dunia pendidikan: bahasa pengajaran, pendidikan bilingual, pembelajaran bahasa asing; penggunaan bahasa dalam ranah agama (Kartubi, 2010:5).

Penelitian ini menggunakan kuesioner terbuka yang berisi lima butir pertanyaan untuk mengukur data sikap bahasa. Pengambilan data menggunakan 
20 responden berasal dari satu RT di kelurahan Kota Alam Lampung Utara.

\section{B. PEMBAHASAN}

Di bawah ini pemaparan hasil kuesioner yang diajukan oleh penulis kepada tujuh responden terkait dengan sikap bahasa masyarakat Lampung terhadap bahasa nenek moyangnya.

1. Apakah Anda merasa malu memakai bahasa daerah Lampung dengan ragamnya?

Hasil analisis data menunjukan bahwa $100 \%$ responden tidak pernah berada dalam situasi yang membuat mereka malu menggunakan bahasa Lampung di daerah sendiri. Namun di daerah tertentu $15 \%$ responden merasa malu menggunakan bahasa Lampung. Bahkan berdasarkan penelitian Kartubi (2010:5) bahwa 8\% dari 145 responden di Jabung Kotabumi Lampung Utara menyatakan bahwa mereka merasa malu menggunakan ragam bahasa daerah mereka sendiri ketika mereka pergi ke daerah lain. Alasannya adalah "Lebih baik menggunakan bahasa yang dipahami tiap orang, agar komunikasi dapat terjalin, yaitu bahasa Indonesia."
2. Bahasa apa yang Anda gunakan ketika marah?

Hasil analisis data menunjukkan bahwa $100 \%$ responden mengatakan bahwa mereka selalu menggunakan bahasa daerah ketika marah. Hal itu berarti bahwa penggunaan bahasa dalam ranah privat masih menggunakan bahasa daerah.

3. Bahasa apa yang Anda gunakan ketika ada sesuatu yang lucu di sekitar Anda?

Hasil analisis data menunjukkan bahwa $100 \%$ responden selalu menggunakan bahasa daerah ketika menceritakan hal yang lucu atau bercanda. Hal ini memiliki kesamaan argumen dengan pertanyaan kedua, yakni dalam ranah privat mereka masih mempertahankan bahasa Lampung.

4. Bahasa apakah yang seharusnya anak-anak gunakan di rumah maupun di luar rumah?

Hasil analisis data menunjukkan bahwa $85 \%$ responden setuju anakanak menggunakan bahasa Lampung di rumah dan di luar dengan alasan melestarikan bahasa daerah. Namun 15\% responden lainnya memilih bahwa anak-anak harus diajarkan menggunakan bahasa Lampung di rumah, dan 
menggunakan bahasa Indonesia di luar rumah dengan alasan agar mudah bergaul, berbaur dengan teman lainnya.

5. Apakah Anda tertarik membaca/menulis dalam bahasa daerah Anda?

Hasil analisis data menunjukkan $60 \%$ responden tertarik untuk mengetahui atau membaca/menulis dalam aksara lampung. Dengan alasan bahwa mereka bangga dengan bahasa daerah mereka dan malu sebagai pribumi asli Lampung jika tidak mengetahui aksara Lampung. Sementara $40 \%$ responden tidak tertarik untuk membaca/menulis dalam bahasa daerah mereka, dengan alasan bahwa mereka lebih suka membaca dan menulis dalam bahasa Indonesia karena bahasa Indonesia adalah bahasa nasional dan memiliki pemakaian yang lebih luas dibanding bahasa Lampung.

\section{SIMPULAN}

Berdasarkan hasil penelitian yang telah dilakukan berkaitan dengan sikap masyarakat Lampung tentang bahasa daerah mereka sendiri ditemukan bahwa mayoritas dari 20 responden yang diambil dari satu RT di kelurahan Kota Alam
Lampung Utara tidak malu untuk menggunakan bahasa Lampung di daerah mereka sendiri, bahkan dalam keadaan marah dan sedang membicarakan sesuatu yang sifatnya privasi pun responden memilih untuk menggunakan bahasa Lampung. Artinya sedikit sekali responden yang negatif terhadap bahasa daerah mereka sendiri, hanya situasi-situasi tertentu saja yang mereka tidak menggunakan bahasa daerah.

\section{DAFTAR RUJUKAN}

Kartubi. 2010. Sikap Bahasa Penutur Jati Bahasa Lampung. Jakarta:(PMB)LIPI

Baker, Colin. 1992. Attitudes and Language. Adelaide: Multilingual Matters Ltd.

Lambert, W. W., \& Lambert, W. E. (1973). Social psychology (ed. ke-2). Englewood Cliffs, N.J.: Prentice-Hall, Inc.

Ghazali Yusri, Nik Mohd Rahimi, \& Parilah M. Shah. 2010. Sikap pelajar terhadap pembelajaran kemahiran lisan bahasa arab di Universiti Teknologi MARA (UiTM). GEMA Online ${ }^{\mathrm{TM}}$ Journal of Language Studies, 10(3), 15-33. 